\title{
Life cycle performance of aluminium applications: foreword
}

\author{
Rudolph P. Huber
}

Received: 5 March 2009 / Accepted: 6 March 2009/Published online: 24 March 2009

(C) Springer-Verlag 2009

\section{Dear Readers,}

We are proud that our industry can collaborate with the "International Journal of Life Cycle Assessment" to showcase the importance of life cycle thinking for the aluminium industry.

Did you know that three quarters of all the aluminium ever produced since the 1880 s are still in productive use? This stock has grown to about 600 million tonnes. Of the aluminium currently stored in productive use, about one third can be allocated to buildings for window frames, roofing, cladding, etc.; one third to transport in the automotive sector, for public transport, etc. and one third to engineering and packaging applications.

The global stock of aluminium in productive use is growing every year. As you can read in this special issue, our industry has for long recognised the value of tracking the material we produce and converting it into valuable products. And it is because of its high durability and easy recyclability that this resource can be used over and over again.

So life cycle thinking is embedded in the aluminium industry. We acknowledge the environmental burden of producing the primary metal, but the industrial companies

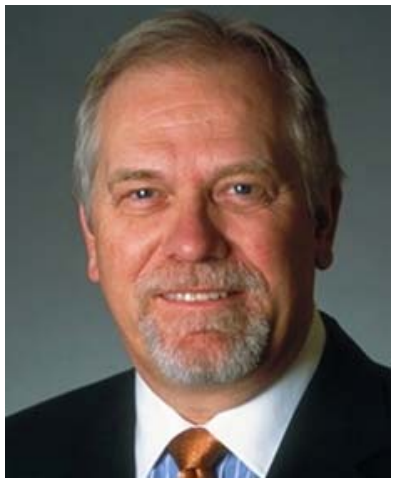

collaborate in continuously reducing this burden. With the help of life cycle assessment, the industry has been able to demonstrate, for many applications in all major markets, the overall net benefits resulting from the use of aluminium. The importance of sound scientific methods and studies to assess our products has continuously grown as sustainability is entering the competitiveness agenda of all industrial sectors.

Rudolph P. Huber

Chairman of the European Aluminium Association

Responsible editor: Gerald Rebitzer and Jörg Schäfer

Special Issue "Life Cycle Performance of Aluminium Applications"

R. P. Huber $(\square)$

European Aluminium Association,

Avenue de Broqueville, 12,

1150 Brussels, Belgium

e-mail: eaa@eaa.be

URL: www.aluminium.org 